\title{
Trade Liberalization, Openness, and Economic Growth in Sri Lanka: A Co-Integration Analysis
}

\author{
Nirodha De Silva*1, Benaissa Chidmi ${ }^{2}$, \\ Jeff Johnson ${ }^{3}$ \\ Department of Agricultural and Applied Economics, \\ Texas Tech University, Lubbock, TX
}

\begin{abstract}
This study attempted to show the relationship between trade liberalization and economic growth in Sri Lanka over the period of 1960-2010. This paper empirically estimated the causality relationship between trade openness and economic growth by employing co-integration and Granger -causality tests. The analysis supports the long run relationship between trade openness and economic growth. This study also concluded investments and Free Trade Agreements are significant and positively related to the economic growth and showed that both factors are feasible in sustaining economic growth in Sri Lanka.
\end{abstract}

Keywords Component: Trade Liberalization, Trade Openness, Economic Growth, Investment, Free Trade Agreements, Co-integration, Causality, Error Correction Model, Sri Lanka

\section{INTRODUCTION}

Trade liberalization is considered a significant economic tool to promote economic growth of a country [1]. Trade liberalization and market- oriented policy reforms were widely adopted in many developing countries in the early 1980 s and intensified in the 1990s. Complete elimination of trade barriers has become the most popular economic policy of developed and developing nations today [2]. Before the 1980s, government intervention was higher in the agricultural sector in both developed and developing countries [3]. Import and export tariffs, quotas, export subsidies, and technical barriers became inhibitors of the popular trade during the last decades [4]. Some studies show that trade is not only an engine of growth but it sustains growth [5]. A positive link between economic growth and trade

"Corresponding Author: Nirodha De Silva, Graduate Student, Department of Agricultural and Applied Economics, Texas Tech University, Box 42132, Lubbock, TX 79409.Phone:806-7422464 ext:229.

Email: $\quad$ k-v-nirodha-sudershini.de-silva@ttu.edu; nirodhakam@yahoo.com openness may prove that trade liberalization increasingly evolves as most economies develop. As a developing nation, Sri Lanka has been implementing trade liberalization policies since the late 1980s.

Some researchers argue that there is little or no evidence to prove that trade liberalization involves accelerating economic growth. However, nearly all the empirical evidence confirms that there is a link between trade openness and growth which results from trade liberalization [6]. Various studies including Edwards [7], Ballasa [8], Ahmed [9], Sarkar [10], Anderson and Babula [6], Awokuse [11], Alessandrini, Fattouh, Ferrarini and Scarmozzino [12] show that there is a positive relationship between trade openness and economic growth.

Sri Lanka introduced market oriented economic policies in 1977, and the Gross Domestic Product (GDP) has been growing at an approximate annual average of 5.0 -5.5 percent. Even though Sri Lanka introduced trade policy reforms, along with export, import, and tariff liberalizations, the economic growth rate was not higher as expected until 2010. A few studies have been carried out on this issue; however, these findings produced conflicting results [4]. Therefore, this study empirically investigates the relationship between trade liberalization and economic growth of Sri Lanka using time series models including Johansen co-integration test, Granger-causality, and error correction mechanism. The general objective of the study is to show the long run relationship between trade openness and economic growth and to determine the causal relationship between trade openness and economic growth. This research further examines whether Sri Lanka has gained economic benefits from the regional Free Trade Agreements (FTA) like SAFTA (South Asian Free 
Trade Agreement) or ILFTA (India Sri Lanka Free Trade Agreement).

In this paper, we empirically estimated the impact of trade liberalization on economic growth in Sri Lanka using a co-integration approach for the period of 1960 to 2010. The rest of the paper consists of four sections. Section two describes the review of the empirical literature, while section three illustrates econometrics modeling framework and data. Section four reports results and discussion. Finally, section five includes summary and concluding remarks.

\section{REVIEW OF THE LITERATURE}

Nash and Thomas concluded that trade policy reform leads to higher economic growth in developing countries and showed that supply responses were stronger as institutions and infrastructure supported the reforms and resource allocations [13]. Ahmed found that trade liberalization caused a unique long-run equilibrium relationship among quantities of export, export price and exchange rate in Bangladesh using a cointegration modeling approach [9]. In a major study, Yanikkaya estimated a relationship between trade liberalization and per capita income growth, and he used the trade volume as one of the trade openness measures in the study. Generalized Method of Moments (GMM) estimates of this study indicated that trade volume that measures trade openness is positively related to the per capita income growth, and it was significant [14]. By using the panel data of 42 countries from Asia, Africa, and Latin America, Parikh and Stirbu estimated the relationship between trade liberalization, growth, and balance of payments. This study showed that trade liberalization promoted growth [15]. In another study, Edwards and Alves stated that trade liberalization and export growth are positively related in South Africa [16]. Vamvoukas examined the relationship between trade liberalization and economic expansion using four European countries: Greece, Ireland, Portugal and Spain. By applying a sensitivity analysis with Granger multivariate tests based on error correction modeling, this study suggested that empirical evidence from developing and developed countries are necessary to determine qualitative and the quantitative factors that affect the causality between exports and economic growth [17]. Chaudhry, Malik, and Faridi explored the casual relationship among trade liberalization, human capital growth, and economic growth in Pakistan using cointegration and causality. This study revealed that a long run and short run relationship exists among these factors [1].

Most economic literature illustrated that the majority of studies that focused on trade liberalization and economic growth have been carried out using panel data studies of groups of countries [18]. However, a few studies have been done using time series analysis of a particular economy. Among them, Nath and Al-mamun analyzed trade and economic growth in Bangladesh using a vector auto regression (VAR) model to show that trade has increased the economic growth in Bangladesh [19]. Our study contributes to the literature by analyzing long run dynamics among trade liberalization, openness and economic growth in Sri Lanka. It also determines causality among those variables.

\section{ECONOMETRIC MODELING FRAMEWORK AND DATA}

\section{Data sources}

This study used only the secondary source of time series data which was published in the annual reports of the Central Bank of Sri Lanka [20]. The time period selected was from 1960 to 2010; therefore, the total sample was 51years. By using the GDP deflator of respective years, price effects of variables were removed to avoid the inflationary effects.

Five explanatory variables, namely total agricultural production, trade openness, investment, trade liberalization, and FTA were used for this study to examine the long run effects of trade liberalization on economic growth. Real GDP was the dependent variable in the study. All the statistics of exports, imports, and investments were from the annual reports of the Central Bank of Sri Lanka. Five time series were generated from which economic growth captures the trade openness effects through trade liberalization policies.

In this study, Sri Lanka's real Gross Domestic Product (GDP) was used as the proxy for economic growth in the country. Trade openness was defined as the ratio of the total export (X) and imports (M) to total GDP (X+M/GDP). Trade openness is assumed to have a positive impact on economic growth because the ratio of total exports and imports as well as their combined total to GDP $(\mathrm{X}+\mathrm{M}) / \mathrm{GDP})$ are expected to increase with trade liberalization. In this analysis, total investments included both domestic and foreign investments, and they are assumed to have a positive relationship with economic growth because trade policy reforms build an investment friendly environment by 
attracting foreign firms and gradually increasing employment opportunities, thus contributing to economic growth. The total real GDP of the agricultural sector compared to the total real GDP was considered the total agricultural production in this study. This total agricultural production is assumed to have a positive relationship with economic growth as an increase of agricultural sector output provides a significant share to the total GDP. D1 was the dummy variable for trade liberalization ( $\mathrm{D} 1=0$ before 1977 or closed economy, and D1=1 after 1977 or trade liberalization) and the objective of this variable was to check whether there is a change in the total GDP growth after introducing the market economy in 1977. D2 was the dummy variable for Free Trade Agreement (D2=1 after 1995, and D2=0 for the period of 1977 to 1995) and this FTA dummy variable aimed to study the impacts of trade liberalization with FTAs on economic growth in Sri Lanka after 1995. The time series analysis was performed using SAS as the analytical tool.

\section{Model Structure}

The five variables used in the analysis were incorporated into the time series regression model.

The general Regression Equation used as of form:

Economic Growth $=\beta_{0}+\beta_{1}$ Totalagriculproduct $+\beta_{2}$ Trade Openness ${ }^{+} \beta_{3}$ Investments $+\beta_{4}$ Trade Liber+ $\beta_{5}$ FTA $+u_{i}$

This study applied time series econometrics to investigate the long run dynamics between trade liberalization and economic growth. Co-integration, error correction models, and Granger causality tests were used to determine the order of integration for the long run relationship and to find the causality of variables of the study. The OLS estimation of regression in the presence of non-stationary variables yields spurious regression [21]. This further confirms that stationarity of variables is an essential component in the time series analysis, and those stationary variables produce reliable and more accurate results.

The Augmented Dicky-Fuller (ADF) test was employed to check the stationarity of the variables. $\mathrm{ADF}$ is a unit root test that reports the correlation between error terms and includes the lag value of the dependent variable in the regression. The optimal lag length was determined by the AIC
(Akaike Information Criteria) and the SBC (Schwarz Bayesian Criterion).

The time series were examined for the co-integration to assess the long run dynamics of the variables. In this study, the Johansen cointegration test was used to test the long run movements of the variables. Finally, Granger causality procedure was applied to analyze the causality between trade openness and economic growth in the long run.

\section{V. EMPIRICAL RESULTS AND DISCUSSIONS}

The regression results of the model confirm that there is a spurious regression as the Coefficient of the Determinations, R-squares for the model, is 96 percent $(0.96>0.95)$. Overall, this model supports the regression to be spurious because there is a higher R-square and significant tratios. This situation leads to the application of time series techniques. After confirming the spurious regression results, the variables were checked for stationarity. The unit root test was applied on the level values of time series. The results of the Augmented Dickey-Fuller test are shown in table 2 and suggest that all the variables are non-stationary except total Agricultural production, D1, and D2. However, trade openness and investments were stationary in the first differencing level (Table 3).

Table 2. Results of Augmented Dicky-Fuller Unit Root Test to Check the Stationary of Time Series at Level Values

\begin{tabular}{|lll|}
\hline $\begin{array}{l}\text { Variables } \\
\text { of test }\end{array}$ & P-values & \\
\hline Total agri prodn & & ADF \\
Trade openness & $0.0001^{* *}$ & ADF \\
Investments & 0.2455 & ADF \\
D1 & 0.8988 & ADF \\
D2 & $0.0001^{* *}$ & ADF \\
\hline
\end{tabular}

Note:**denote significance at the $5 \%$ level 
Table 3. Results of Augmented Dicky-Fuller Unit Root Test to check the Stationary of Time Series for Trade Openness and for Investments at First Difference Values

\begin{tabular}{|lll|}
\hline $\begin{array}{l}\text { Variables } \\
\text { of test }\end{array}$ & Type \\
\hline Trade openness & $0.0023^{* *}$ & ADF \\
Investments & $0.0001^{* *}$ & ADF \\
\hline
\end{tabular}

Note:**denote significance at the $5 \%$ level.

\section{Co-integration Analysis}

The study empirically estimated whether a significant relationship exists between trade openness and the real GDP in the long run. For the co-integration between trade openness and the real GDP, the results of Johansen Co-integration analysis are shown in table 4 .

Table 4. Results of Co-integration Test

\begin{tabular}{|llllll|}
\hline \multicolumn{5}{|l|}{ Co-integration Rank Test for I(2) } \\
\hline rlk-r-s & 2 & 1 & $\begin{array}{l}\text { Trace } \\
\text { of I(1) }\end{array}$ & $\begin{array}{l}5 \% \mathrm{CV} \\
\text { of I(1) }\end{array}$ \\
0 & 125.9669 & 50.3910 & 17.4764 & 15.34 \\
1 & & 50.3095 & 1.7517 & 3.84 \\
$5 \%$ & CV & 15.34000 & 3.84000 & & \\
I(2) & & & & \\
\hline
\end{tabular}

Table 5. Eigenvalues for Co-integration Rank Test for I(2)

\begin{tabular}{|lccl|}
\hline $\begin{array}{l}\text { Eigenvalues } \\
\mathrm{I}(2)\end{array}$ & for & Co-integration & Rank Test for \\
\hline $\mathrm{r} \backslash \mathrm{s}$ & 0 & 1 & $\begin{array}{l}\text { Eigenvalue of } \\
\mathrm{I}(1)\end{array}$ \\
0 & 0.786126 & 0.642417 & 0.2745 \\
1 & 0.641822 & 0.0351 \\
\hline
\end{tabular}

Table 5 explains the co-integration rank test with integrated order 1 . The results show that there is a co-integrated relationship with the integration rank 1 with respect to the 0.05 significance level because the trace-test statistic of 1.7517 is smaller than the critical value of 3.84. There is no evidence that the series are in the integrated order 2 at the 0.05 significance level. Both the trace-test and the
Eigenvalue statistic illustrate that there is a cointegration between trade openness and economic growth.

\section{Long Run Relationship}

Since the variables of the model were cointegrated, the relationship between dependent and exogenous variables can be estimated in the long run. The Ordinary Least Square regression was employed to show the parameter estimates of the variables. Table 6 indicates the long run relationship between the variables.

Table 6. Regression Results to Estimate the Impacts of Trade Liberalization and Trade Openness on Economic Growth

\begin{tabular}{|lccll|}
\hline Variable & DF & $\begin{array}{c}\text { Parameter } \\
\text { Estimate }\end{array}$ & $\begin{array}{l}\text { Standard } \\
\text { Error }\end{array}$ & $\operatorname{Pr}>|t|$ \\
\hline Intercept & 1 & -162.1605 & 89.5489 & 0.0770 \\
totalagriprocucn1 & 1 & 0.1136 & 0.24297 & $0.0423^{* *}$ \\
tradeopeness1 & 1 & 3780.5058 & 10640 & 0.7240 \\
investments1 & 1 & 0.0018 & 0.0007 & $0.0174^{* *}$ \\
D1 & 1 & -251.7709 & 104.4819 & $0.0202^{* *}$ \\
D2 & 1 & 598.84257 & 113.3385 & $0.0001^{* *}$ \\
\hline
\end{tabular}

Note: $* *$ denote significance at the $5 \%$ level.

The R square $=0.5958$

Adj R-Square $=0.5407$

Table 6 shows that more than 54 percent of the total variation in the real GDP is explained by the regression model. Intercept and all the variables are significant at 5 percent level except the trade openness. Real GDP increased by 0.11363 units with unit increase of agricultural production. Trade openness is positively related to the real GDP, but it is not a significant factor of real GDP. Investment is a significant determinant at 5 percent and shows that real GDP increases by 0.0017 units with a unit increase of investment. The D2 variable for Free Trade Agreements (FTA) is positively related to the economic growth. On average the real GDP is higher by 598.8425 units in the post FTA period. Moreover, the FTA variable is a significant determinant of economic growth at 5 percent significance. The D1 variable for the Trade liberalization is significant, but it is not positively related to economic growth.

Since this study observed a long run relationship between the variables, it is possible to 
explore an Error Correction Model (ECM) framework to determine the short run relationship in behavior of real GDP. The ECM captures past disequilibrium in the long run as exogenous variables, and it adjusts in capturing both short run and long run dynamics among the variables.

ECM can be represented as

(1-B) realGDP $=\beta_{0}+\beta_{1}$ Totalagriculproduct $+\beta_{2}$ (1-B) Trade Openness $+\beta_{3}(1-\mathrm{B})$ Investments $+\beta_{4}$ D1+ $\beta_{5} \quad$ D2 $+e_{t}$

In this study, $e_{t}$ has the order of $\operatorname{AR}(2)$ and it has following form:

$\mathrm{e}_{\mathrm{t}}=\theta_{1} \mathrm{e}_{\mathrm{t}-1}+\theta_{2}$ et- 2

Therefore, this equation has the two lagged values of error terms which were obtained from long run relationship among the variables. The results of Error Correction Model are shown in the table 7 .

Table 7. Results of Error Correction Model to Estimate the Short Run Dynamics between Trade Liberalization Polices on Economic Growth

\begin{tabular}{|c|c|c|c|}
\hline \multicolumn{4}{|c|}{$\begin{array}{l}\text { Conditional Least Squares Estimation } \\
\text { Dependent Variable }=\Delta \text { real GDP }\end{array}$} \\
\hline Variable & Estimate & $\begin{array}{l}\text { Standard } \\
\text { Error }\end{array}$ & $\operatorname{Pr}>|t|$ \\
\hline MU & 200.0884 & 156.5036 & 0.2090 \\
\hline$e_{t-1}$ & 0.9733 & 0.1587 & $<.0001$ \\
\hline$e_{t-2}$ & -0.3790 & 0.1717 & 0.0336 \\
\hline tradeopeness & 3563.7 & 7927.1 & 0.6557 \\
\hline investments & 0.0026 & 0.0006 & $<.0001 * *$ \\
\hline Totalagriprodn & -0.4417 & 0.1423 & $0.0036 * *$ \\
\hline D1 & 213.0654 & 214.4189 & 0.3268 \\
\hline D2 & 776.0651 & 186.9317 & $0.0002 * *$ \\
\hline
\end{tabular}

Note: $* *$ denote significance at the $5 \%$ level.

The R square $=0.9953$

Adj R-Square $=0.9960$

According to the results, trade liberalization and trade openness are not significant factors on economic growth in the long run. However, they are positively related to the economic growth in Sri Lanka. Total investment is positively related and it is a highly significant factor of economic growth. Real GDP is increased by 0.002 units with each unit increase of investment. Total agricultural production is significant, but it is negatively related to the real GDP. FTA variable indicates a positive relationship and it is significant. This highlights the fact that the overall trade policy framework adopted after 1977 has promoted the economic growth of Sri Lanka. The variable $\mathrm{e}_{\mathrm{t}-1}$ and $\mathrm{e}_{\mathrm{t}-2}$ are significant, and they have correct signs. The coefficients of the $\mathrm{e}_{\mathrm{t}-1}$ and $\mathrm{e}_{\mathrm{t}-2}$ indicate speed of adjustments and suggest the validity of long run relationship among the variables.

This analysis shows that there exists a long run relationship between trade openness and economic growth in Sri Lanka. With the established co-integration, VAR causality can be estimated to determine the cause and effect behavior of the trade openness and total GDP. Fig.1 presents the results of the Long Run causality of trade openness and economic growth. Results of the Grangers-causality test shows that we can reject the null-hypothesis that trade openness is influenced by itself and not by the real GDP at the 0.05 significance level for Test 1. Also, we can reject the null- hypothesis that that real GDP is influenced by itself and not by the trade openness at the 0.05 significance level for Test 2. This further confirms that trade openness has impacts on real GDP and real GDP also has impacts on trade openness in the long run. This shows that there is not a unidirectional causality between trade openness and real GDP.

\begin{tabular}{|l|l|l|}
\hline Test & Chi-Square & $\operatorname{Pr}>$ ChiSq \\
\hline 1 & 6.64 & 0.0364 \\
\hline 2 & 4.42 & 0.0208 \\
\hline
\end{tabular}

\begin{tabular}{|l|l|}
\hline Test 1: Group 1 Variables: & tradeopeness 1 \\
\hline Group 2 Variables: & realGDP1 \\
\hline \multicolumn{2}{|l|}{} \\
\hline Test 2: Group 1 Variables: & realGDP1 \\
\hline Group 2 Variables: & tradeopeness 1 \\
\hline
\end{tabular}

Figure 1. Results of Granger-Causality Wald Test 


\section{SUMMARY AND CONCLUDING REMARKS \\ Summary}

This study investigated the empirical evidence on the relationship between trade liberalization, trade openness, and economic growth using time series models. Moreover, the study examined the impacts of investment, Free Trade Agreements and policy reforms on real GDP growth. The empirical results were based on Johansen Co-integration test, Grangers causality, and error correction models. Results show that trade liberalization and trade openness has no significant effects on economic growth, although they are positively related to the economic growth. Free Trade policies would be beneficial for the economy if those policies made a significant impact on real GDP by allocating domestic resources efficiently. However, the study found that the trade agreements such as the India-Sri Lanka Free Trade Agreement and the South Asia Free Trade Agreement (SAFTA) have had considerable influence in increased economic growth. These agreements were implemented during the post liberalization period and introduced liberalization programs like tariff reduction, Safeguard Measures, and new institutional arrangements. This shows that trade policy reforms may have significantly accelerated economic growth in post liberalization period in Sri Lanka.

Similarly, results show that total agricultural production and economic growth is negatively related. This suggests the relationship between trade liberalization and real GDP growth is more complicated. If the government provides facilities to increase economic growth, then there would be a decrease in agricultural production in the country.

This analysis also reveals that the error correction term for the real GDP is significant, and it may show that there exists a long run stable relationship between trade openness and real GDP. From the results presented above, we may conclude that there is a cause and effect behavior of trade openness and real GDP because causality runs from real GDP to trade openness and from trade openness to real GDP. This further shows that there is a bi-directional significant relationship between the trade openness and the real GDP.

These findings also imply that the investment is positively related to the economic growth and is a significant variable, and it further explains that domestic and foreign investment accelerated economic growth. Therefore, trade liberalization policies introduced in 1977 have increased the allocation of investment to productive activities especially for the manufacturing and industrial sectors. This may confirm that changes of trade policies have attracted the foreign and domestic investments and this increased investment has accelerated the economic growth of Sri Lanka.

These results confirm the well-established positive impact of market liberalization on economic growth during the post liberalization period in Sri Lanka. Overall, liberalization seems to have significantly contributed to the acceleration of economic growth and investment level over the period of 1977-2010. Specifically, this analysis concludes that it requires creating an investmentfriendly environment in promoting economic growth in Sri Lanka. Simultaneously, the government should prioritize the increase of international competitiveness by giving stronger emphasis to export diversification.

\section{REFERENCES}

[1] I. S. Chaudhry, A. Malik, and M. Z. Faridi, "Exploring the Causality Relationship between Trade Liberalization, Human Capital and Economic Growth: Empirical Evidence from Pakistan," Journal of Economics and International Finance, vol.2, no.8, pp.175-182, Sep. 2010.

[2] (Online Sources style) H. Herath. (2010). "Impacts of Trade Liberalization on Economic Growth of Sri Lanka." Available: http://www.kln.ac.lk/uokr/ICBI2010/6.pdf

[3] S, Anwar ,F. Shaukat, and Z. Hussain, "Impact of Trade Liberalization on Export of Cotton from Pakistan: A Time Series Analysis." Agriculture. vol. 26, no.2, pp. 297-304, 2010.

[4] N. De Silva, J. Malaga, and J. Johnson, "Trade Liberalization Effects on Agricultural Production Growth: The Case of Sri Lanka (Presented Conference Paper Style)," presented at the SAEA annual conference, Orlando, Fl, February 02-05, 2013.

[5] A. Dreher, "Does globalization affect growth? Evidence from a new index of globalization (Journal style),".Applied Economics, vol.38, no.10,pp.1091-1110, Sep 2006.

[6] (Online Journal style) L. Andersen and R. Babula, (2008, July). The Link Between Openness and Long-Run Economic Growth. Journal of International Commerce and Economics. Available:http://www.usitc.gov/publications/332/journals/openn ess_growth_link.pdf.

[7] S. Edwards, "Openness, Trade Liberalization, and Growth in Developing Countries(Journal style)," Journal of Economic Literature, vol.31, pp.1358-1393, 1993

[8] B. Balassa, "Export and Economic Growth: Further Evidence (Journal style)," Journal of Development Economics, vol.5, no.2, pp. 181-189. June, 1978.

[9] N. Ahmed, "Export Responses to Trade Liberalization in Bangladesh: A Co-integration analysis (Journal style)," Journal of Applied Economics, vol.32,no. 8,pp. 1077-84. 2000. 
[10] (Online Journal style) P. Sakar, (2005, Oct). Is There any Impact of Trade Liberalization on Growth? Experiences of India and Korea. Available: http://mpra.ub.uni-muenchen.de/5177/ MPRA_paper_5177.pdf

[11] T. Awokuse, "Trade Openness and Economic Growth: Is Growth Export- Led or Import -Led(Journal style)?," Applied Economics, vol.40, no.2, pp. 161-173. 2008.

[12] M. Alessandrini, B. Fattouh, B. Ferrarini, and P. Scaramozzino, "Tariff Liberalization and Trade Specialization in India". ADB Economics Working Paper Series 177, Asian Development Bank. 2009.

[13] V. Thomas and J. Nash, "Reform of Trade Policy: Recent Evidence from Theory and Practice(Journal style)," The World Bank Research Observer, vol.6, no.2, pp. 49-53. 1991.

[14] H. Yanikkaya, "Trade Openness and Economic Growth: A Cross Country Empirical Investigation (Journal style)," Journal of Development Economics, vol. 72, no.1, pp. 57-89. Oct, 2003.

[15] A. Pakirikh, and C. Stirbu, "Relationship between trade liberalization, economic growth and trade balance: An econometric investigation." HWWA Discussion Paper, Hamburgisches Welt-Wirtschafts- Archiv (HWWA) Hamburg Institute of International Economics. 2004

[16] L.Edwards, L and P. Alves, "South Africa's Export Performances: Determinants of Export Supply. Africa Region Working Paper Series No.05, School of Economics, University of Cape Town, December, 2005.

[17] G.Vamvoukas, "Trade Liberalization and Economic Expansion: A Sensitivity Analysis (Journal style)," South Eastern Europe Journal of Economics, vol.1, pp.71-88. 2007.

[18] R.E. A. Khan and H.N. Bashir, "Trade Poverty, and Inequality Nexus: The Case of Pakistan(Journal style)," World Applied Sciences Journal, vol.18, no.5, pp.722-726. 2012.

[19] H. K.Nath and K. Al-Mamun, "Trade Liberalization, Growth, and Inequality in Bangladesh: An Empirical Analysis (Presented Conference Paper style)," presented at the 41st Annual Conference of the Missouri Valley Economic Association, Nashville, TN, Oct, 2004.

[20] Central Bank of Sri Lanka( Report Style), Annual Report, Colombo, 2010

[21] C. Granger and P. Newbold, " Spurious Regressions in Econometrics (Journal style)," Journal of Econometrics, vol. 2, pp. 111-120. 1974.

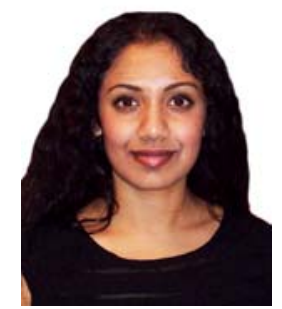

Nirodha De Silva is currently a Ph.D. student in the Department of Agricultural and Applied Economics at Texas Tech University, Lubbock, TX, USA. She received her B.S degree in Agriculture with Specialization of Agricultural Economics from University of Peradeniya, Sri Lanka, in 2003. She completed her master's degree in Environmental Economics from Post Graduate Institute of Agriculture, University of Peradeniya in 2005. She also received a master's degree in Natural Resource Management in 2008 from North Dakota State University, USA. She joined the Department of Agricultural and Applied Economics at Texas Tech University, USA in 2012. Her current research includes the impact of trade liberalization and openness on economic growth in Sri Lanka, and assessing the economic value of ground water in the Ogallala Aquifer in West Texas, USA.

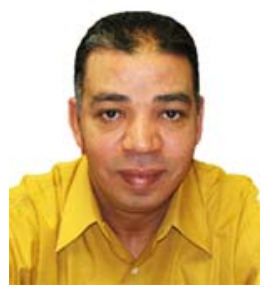

Dr. Benaissa Chidmi is an Associate Professor at the Department of Agricultural and Applied Economics at Texas Tech University. Dr. Chidmi received his Ph.D. in Agricultural and Resource Economics and Master's in Applied Financial Mathematics from the University of Connecticut in 2006. Dr. Chidmi's research interests include empirical industrial models applied to business strategies, consumer demand applied to marketing, vertical relationship modeling, microeconomics and agribusiness. Dr. Chidmi's teaching responsibilities at the Agricultural and Applied Economics include Applied Econometrics I, Applied Econometrics II, Applied Econometrics III, and Demand and Price analysis at the graduate level. 


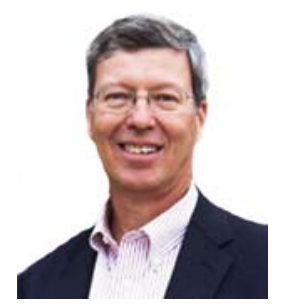

Dr. Jeff Johnson is currently an Associate Professor with appointments in the Department of Agricultural and Applied Economics at Texas Tech University and Texas A\&M AgriLife Research in Lubbock. He is actively engaged in research, teaching, and administration. His research interests include water policy, irrigation economics, and farm management. $\mathrm{He}$ teaches undergraduate classes in farm management and property appraisal and graduate classes in resource economics and economics of production agriculture. As Associate Director of CASNR Water Center, he coordinates and facilitates multidisciplinary water-related research for the College of Agricultural Sciences and Natural Resources (CASNR) at Texas Tech University. 